\title{
PERBANDINGAN METODE ANALISIS CIRI AIR UNTUK PENDETEKSIAN OBJEK PERMUKAAN AIR BERDASARKAN PANTULAN CAHAYA
}

\author{
Surya Hadinata \\ Jurusan Teknik Informatika, STMIK Potensi Utama, \\ Jln. KL. Yos Sudarso Km. 6,5 No. 3-A- Tanjung Mulia, Medan 20241 \\ info@potensi-utama.ac.id
}

\begin{abstract}
Water is one of the unique objects in nature. In computer vision applications, object identification mechanism of water can be done by analyzing the light on the object, either by analyzing the reflection or absorption of light. In addition, the approach in the detection of surface water must also consider the adequacy of the light source and some properties of water associated with the propagation of light, ie the water surface conditions (calm, wavy), the status of depth, turbidity, and presence or absence of material that floats on the water surface such as foam or other materials). The nature of this water will affect the reflection or absorption of light, which would affect the number of variations that must be defined for the detection of water. Several research approaches for detecting the water level that has been done is a color image classification method with color imagery and analysis of light polarization. This research is a study of research literature related to the mechanism of water detection using 2 methods. Discussion is to do the comparison includes comparing the descriptions of equipment and removal of surface water scenario based approach to the properties of water. Then, the comparison of image segmentation is arranged based on the said pattern identification.
\end{abstract}

Keywords: polarization of light, color imagery, detection of water surface

\begin{abstract}
ABSTRAK
Air merupakan salah satu objek yang unik di alam. Pada aplikasi komputer vision, mekanisme identifikasi objek air dapat dilakukan dengan menganalisis cahaya yang mengenai objek tersebut, baik dengan menganalisis pantulan atau penyerapan cahaya. Selain itu, pendekatan dalam deteksi permukaan air pun harus memperhatikan kecukupan sumber cahaya serta beberapa sifat air yang berkaitan dengan perambatan cahaya, yaitu keadaan permukaan air (tenang, bergelombang), status kedalaman, tingkat kekeruhan, dan ada tidaknya material yang mengambang pada permukaan air (seperti buih atau bahan-bahan lainnya). Sifat air ini akan mempengaruhi proses pemantulan atau penyerapan cahaya, yang tentunya akan mempengaruhi banyaknya variasi yang harus didefenisikan untuk proses deteksi air. Beberapa pendekatan riset untuk mendeteksi permukaan air yang sudah dilakukan adalah metode klasifikasi warna citra dengan color imagery dan analisis polarisasi cahaya. Penelitian ini merupakan studi pustaka riset yang terkait dengan mekanisme deteksi air menggunakan 2 metode tersebut. Pembahasannya adalah melakukan perbandingan yang meliputi perbandingan dalam deskripsi alat dan skenario pemindahan permukaan air berdasarkan pendekatan sifat-sifat air. Lalu, perbandingan segmentasi citra yang disusun berdasarkan pola identifikasi itu.
\end{abstract}

Kata kunci: polarisasi cahaya, color imagery, deteksi permukaan air

\section{PENDAHULUAN}

Riset pada bidang aplikasi komputer vision untuk mendeteksi objek air pada alam terbuka masih terus mengalami perkembangan. Berbagai pengujian yang dilakukan dalam laboratorium sudah dapat memberikan keberhasilan deteksi dengan baik. Namun, begitu diterapkan ke alam terbuka, ternyata tidak berbeda. Hal ini disebabkan di alam terbuka terdapat beberapa variabel yang harus diperhatikan dan sangat mempengaruhi keberhasilan deteksi permukaan air. Pada sebuah riset (Matthies et al., 2003), telah dilakukan pengelompokan variabel lingkungan yang mempengaruhi kesukaran deteksi air. Variabel lingkungan tersebut adalah variabel waktu operasi (siang atau malam), variabel pemantulan pada permukaan air (yang tentunya akan berbeda dengan air pada tempat terbuka dengan air yang memantulkan banyak pepohonan atau objek di daratan), dan variabel ukuran dari permukaan air (akan berbeda proses identifikasi untuk genangan air yang kecil dibandingkan dengan sebuah danau besar).

Pada semua literatur yang kami pelajari, paling tidak terdapat 3 metode penting dalam riset identifikasi air, yaitu metode penangkapan citra permukaan air, identifikasi ciri air, dan pengolahan akhir. Pemilihan metode-metode ini sangat dipengaruhi oleh variabel lingkungan yang mencirikan air tersebut. Dalam penelitian ini, kami memilih dan membandingkan 2 metode identifikasi ciri air, yaitu metode color imagery (Rankin, 2004) dan polarization imaging (Xie, 2007) yang cukup lengkap dan memiliki tingkat keberhasilan tinggi untuk mendeteksi air. Terkait dengan 2 metode yang dipilih tersebut, maka variabel lingkungan yang dipilih adalah variabel yang berkaitan langsung pada deteksi ciri air berdasarkan pemantulan cahaya pada permukaan air. Sistematika penelitian dimulai dengan pendahuluan. Lalu, bagian kedua akan membahas tentang metode penangkapan citra permukaan air dan dilanjutkan dengan membahas metode 
identifikasi air serta membahas hasil yang diperoleh dari 2 metode deteksi tersebut. Pada bagian akhir, berisi kesimpulan dan beberapa tinjauan yang perlu dilakukan selanjutnya.

\section{METODE PENELITIAN}

\section{Metode Penangkapan Citra Permukaan Air}

Metode ini dibutuhkan dalam rangkaian pengambilan informasipantulan cahaya daripermukaanair. Ketidakakuratan dan kesalahan dalam pemilihan peralatan seperti kamera, filter dan instalasinya tentu akan mempengaruhi akurasi deteksi terhadap objek tersebut (Gambar 1).

Kamera CCD (Charge-Couple Device) komersial yang tersedia di pasaran pada umumnya didesain untuk menangkap intensitas cahaya dan warna dari suatu objek saja. Fungsi ini sudah cukup untuk pengambilan gambar menggunakan metode color imagery. Namun, untuk metode polarisasi cahaya dibutuhkan perangkat tambahan Ada 2 jenis kamera yang yang dapat dimanfaatkan untuk menangkap citra terpolarisasi, yaitu kamera akuisisi citra optik-mekanik (kamera CCD), yang ditambahkan komponen filter polarisasi linier yang dapat dirotasikan secara mekanis di depan lensa kamera tersebut (Wolff and Andreou, 1995) dan kamera akuisisi citra optik elektronik, yaitu kamera yang secara elektronis dilengkapi sensor yang mengatur orientasi polarisasi secara otomatis. Prinsip utama penyusunan skenario penangkap citra adalah memposisikan kamera dengan sudut pantul yang dapat diprediksikan dengan tepat menggunakan teori pantul fresnel.

Beberapa penampilan sifat air dalam color imagery (Rankin, 2004), yaitu intensitasnya lebih terang ketika memantulkan langit dan intensitas yang lebih gelap ketika air berada di bawah bayang-bayang atau ketika memantulkan benda-benda di permukaan tanah yang dekat dan jauh dari permukaan air tersebut. Pada umumnya, skenario untuk penangkapan citra dengan menggunakan metode color imagery ini tidak membutuhkan instalasi yang detail. Yang penting adalah memposisikan kamera pada posisi yang tepat karena pada metode ini kita hanya membutuhkan data-data yang berkaitan dengan intensitas cahaya, yaitu warna, tekstur, dan kisaran pantul (range reflection).

Namun, pada penelitian Matthies (2003) dan Rankin (2004) dengan pertimbangan efisiensi, maka kamera diintegrasikan dengan sistem LADAR (Laser Detection and Ranging), yang merupakan teknologi pengindera jarak jauh dan dapat mengukur properti cahaya yang terhambur untuk menemukan area atau informasi suatu target. Permukaan air yang selalu berada di permukaan tanah mudah diidentifikasi jika disepakati garis horison dari suatu citra. Hal ini akan berguna untuk mengabaikan kesalahan segmentasi warna untuk menentukan dugaan air pada dedaunan di pohon yang tinggi. Penentuan garis horison ini sudah termasuk dalam sistem LADAR tersebut.

Penggunaan polarisasi untuk memahami suatu citra adalah suatu perluasan dari kemampuan mengindera cahaya dari sekedar mengindera intensitas dan warna cahaya. Polarisasi adalah fenomena optik yang sering terjadi di bumi, yang disebabkan oleh 3 keadaan, yaitu proses scattering (hamburan) cahaya matahari dengan atmosfir bumi, polarisasi cahaya pada dunia bawah laut yang disebabkan oleh proses scattering cahaya matahari pada air dan yang ketiga adalah polarisasi cahaya oleh refleksi (pantulan) dari permukaan yang mengkilap seperti permukaan air atau beberapa jenis bahan yang dapat memantulkan cahaya lainnya seperti logam metalik, dan permukaan dielektrik seperti tanah, bebatuan maupun tumbuh-tumbuhan. Cahaya yang datang dari sumbernya (pada alam terbuka adalah matahari) dalam keadaan tidak terpolarisasi akan menjadi terpolarisasi ketika mengalami keadaan-keadaan tersebut. Cahaya terpolarisasi ini mengandung banyak informasi yang bisa dimanfaatkan untuk mengenali objek yang diamati. Informasi polarisasi tersebut meliputi variasi intensitas cahaya yang dihasilkan dari polarisasi, derajat polarisasi, dan sudut polarisasi.

Parameter-parameter polarisasi ini akan menentukan status akhir polarisasi linear parsial. Parameter kedua dan ketiga tersebut adalah perluasan penginderaan objek air dibandingkan cara identifikasi melalui intensitas dan warna pada cara-cara konvensional. Setelah cahaya unpolarized dipantulkan dari permukaan air, maka cahaya menjadi terpolarisasi linier parsial secara horisontal dengan sudut pantul $\psi$.

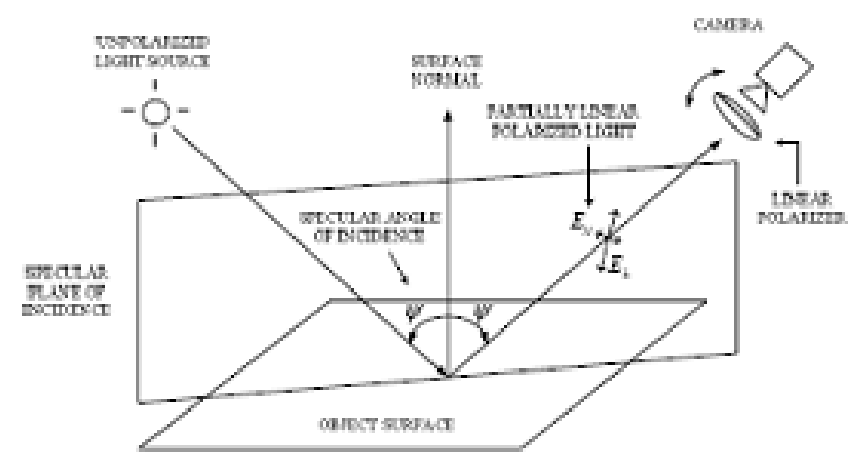

Gambar 1 Prinsip Penangkapan Citra Polarisasi Pemantulan Cahaya pada Permukaan Air (Xie, 2007)

Polarisasi linier parsial ini dikenal juga sebagai derajat polarisasi. Orientasi dari polarisasi linear akan dinyatakan sebagai fase atau orientasi polarisasi, dengan catatan bahwa fase polarisasi bervariasi di dalam kisaran $0-180^{\circ}$. Dengan mengatur fase ini dalam 3 sudut, maka kita akan dapat mengidentifikasi dengan jelas wilayah yang memantulkan cahaya tersebut; yang dalam hal ini adalah ciri dari permukaan air. Skenario pengambilan citra terpolarisasi dapat dilakukan dalam 2 kondisi, yaitu (1) Menggunakan kamera tunggal dengan filter polarisasi linier yang dapat berputar, yang ditempatkan di depan lensa kamera, lalu mengambil 3 citra polarisasi dengan filter polarisasi diset pada $0,45,90$ secara berturut-turut; (2) Menggunakan 3 kamera yang masingmasing kamera diset dalam polarisasi parsial. Kamera pertama dilengkapi filter polarisasi dengan sudut polarisasi pada $0^{\circ}$, yang kedua $45^{\circ}$, dan yang ketiga pada $90^{\circ}$. Masingmasing kamera diposisikan dengan posisi yang hampir sama satu sama lain. Cara pertama lebih mudah untuk diterapkan, tetapi perputaran mekanis filter optis di depan kamera mungkin saja dapat menyebabkan pergeseran geometris proyeksi citra pada bidang fokus dan dapat menimbulkan variasi intensitas pada cahaya. Sedangkan cara kedua dapat menghindari kekurangan cara pertama dan dapat digunakan pada aplikasi yang realtime, namun memerlukan suatu proses kalibrasi yang teliti sebelum pengambilan citra dengan status polarisasi.

\section{Metode Analisis}

Setelah citra objek yang akan diidentifikasi berhasil ditangkap, maka langkah selanjutnya adalah memilih metode analisis ciri air dan menandai areanya. Penjelasan di bawah ini mendeskripsikan langkah-langkah dari 2 metode yang dibandingkan.

Pada metode ini, terdapat 4 langkah analisis air yang digunakan, yaitu mendeteksi ciri air dari warna, tekstur, dan analisis kisaran area (stereo range analysis), lalu hasilnya dipadukan bersama-sama menggunakan aturan dasar, dikembangkan dengan pengolahan beberapa citra stereo warna RGB yang diambil dari berbagai lokasi. Jadi, sebelum metode ini dimulai, terlebih dahulu dilakukan langkah persiapan. Langkah tersebut adalah pengambilan berbagai citra yang mencirikan permukaan air pada alam 
terbuka seperti air tenang, air mengalir, danau, kolam besar, kubangan air kecil, air bening, air keruh, air di bawah bayangbayang sesuatu, dan air di tempat terbuka. Berikut ini adalah citra sumber yang menjadi objek deteksi air yang digunakan dalam penelitian (Rankin, 2004) (Gambar 2).

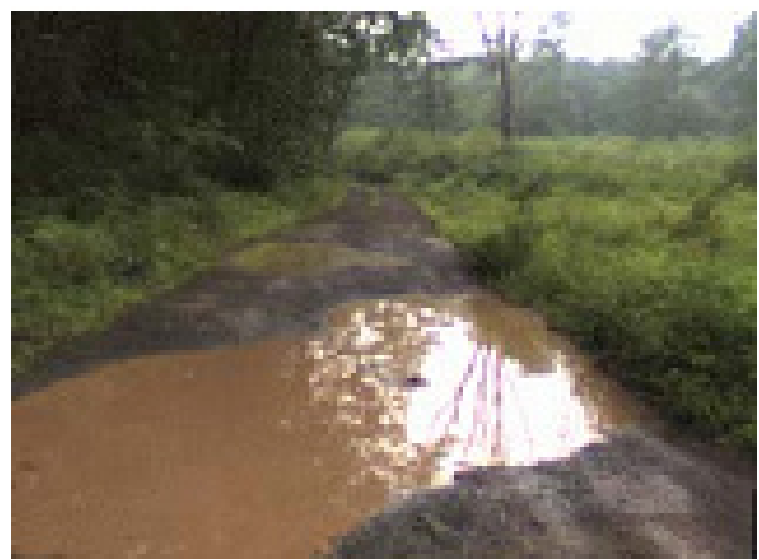

Gambar 2 Citra Sumber Permukaan Air yang Akan Dideteksi (Rankin, 2004)

Penelitian (Rankin, 2004) ini menggunakan kriteria threshold (ambang) berdasarkan evaluasi sekumpulan citra air tadi. Lalu, citra yang diambil dari berbagai sumber alam terbuka diubah ke dalam bentuk area warna Hue, Saturasi, dan Value (HSV); begitu juga citra yang akan dideteksi. Secara konseptual, area warna HSV membentuk kerucut (Gambar 3).

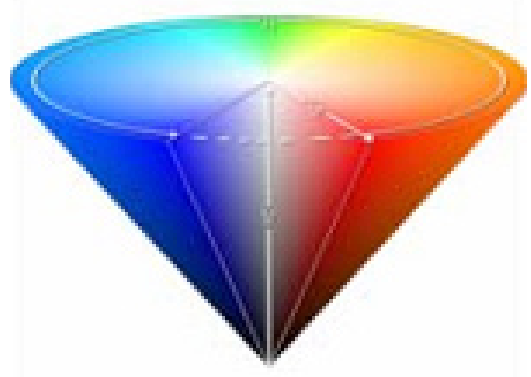

Gambar 3 Area Warna HSV (Cardani, 2001)
Lingkar dari lingkaran kerucut di atas diwakili oleh nilai-nilai hue $\left(0-360^{\circ}\right)$. Saturasi dan nilai (atau brighness) memiliki nilai intensitas $0-1$. Saturasi diwakili oleh jarak dari pusat lingkaran itu. Brighness (kecerahan) diwakili oleh jarak sepanjang poros vertikal kerucut itu. Pada titik ujung kerucut, tidak ada brighness yang diwakili oleh warna hitam. Pada lingkaran kerucut, semua warna berada pada brighness maksimum mereka. Gambar 4 menggambarkan citra grayscale dari brighness dan saturasi untuk genangan air (Gambar 2). Pantulan langit di air mempunyai nilai saturasi rendah dan memiliki nilai brighness yang tinggi. Di sini, kita memusatkan diri dengan mendeteksi pantulan langit di air.

Kriteria threshold di bawah ini diperoleh dari percobaan membaca pola air dari berbagai variasi citra dan digunakan untuk melabelisasi piksel yang merupakan cari air dari warna (Rankin, 2004):

If $[S=0]$ or

$[\mathrm{S} \leq 0.27$ and $\mathrm{B} \geq 0.73]$ or

[sky and $\mathrm{S} \leq 0.1$ and $\mathrm{B}>\mathrm{Bmin}$

(S)] or

[sky and $\mathrm{S}<0.3$ and $\mathrm{B}>\mathrm{Bmin}$

(S) and $240<\mathrm{H}<285$ ], di mana $\mathrm{S}$ adalah saturasi, $\mathrm{B}$ adalah brightness, $\mathrm{H}$ adalah hue (roda warna), dan sky mengacu pada langit terdeteksi atau tidak. Hasil pengolahan citra sumber kemudian dibandingkan dengan kriteria threshold ini, dan menghasilkan segmentasi citra oleh warna (Gambar 5).

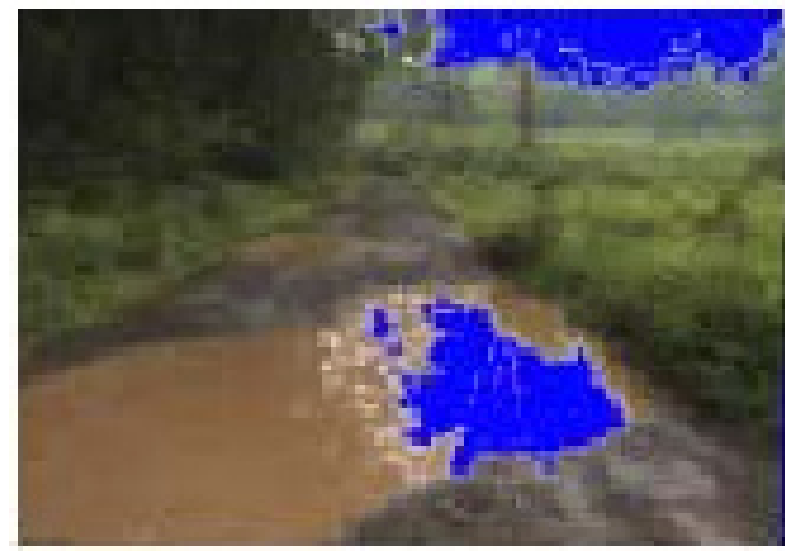

Gambar 5 Pengolahan Citra

(Sumber: Segmentasi dengan Area Warna Hsv (Rankin, 2004))

Kita masih melihat bahwa langit pun diidentifikasi sebagai air karena dengan menggunakan segmentasi area warna HSV ini tidak bisa membedakannya. Kesalahan
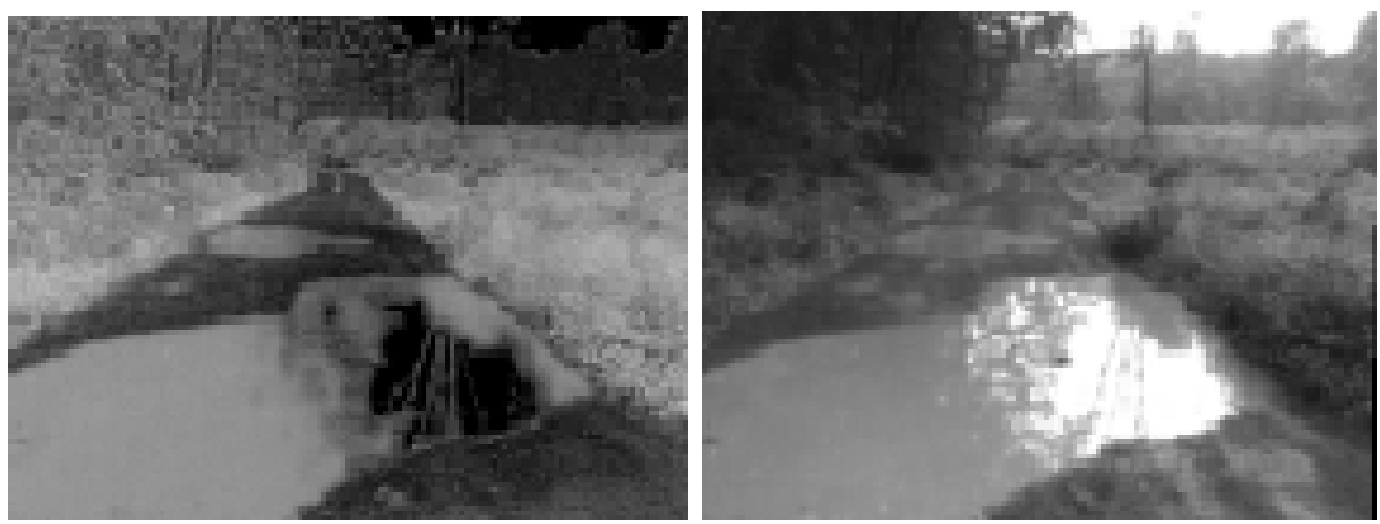

Gambar 4 Pengolahan Citra

(Sumber: saturasi (kiri), brighness (kanan) (Rankin, 2004)) 
ini akan dihilangkan pada saat penggabungan citra ciri air. Tekstur merupakan kuantitasi perbedaan intentitas skala keabuan (atau disebut juga perbedaan kontras). Perbedaan ini biasanya membentuk pola tertentu pada suatu objek yang membedakannya dengan objek yang lain. Untuk ciri air berdasarkan tektur, fakta sifat air yaitu mempunyai tekstur yang rendah (Matthies et al., 2003). Ada 2 pendekatan untuk mengidentifikasi tekstur air, yaitu dengan menggunakan kanal hijau pada RGB dan saturasi citra sumber Gambar 6.

Pada pendeteksian tekstur yang rendah ini, agar mengurangi kesalahan deteksi (Rankin, 2004), perlu diatur tingkat kecerahan threshold minimum dan maksimum pada 75 dan 255 untuk citra channel hijau RGB dan 10 dan 175 untuk citra saturasi. Sebagai tambahan, untuk citra channel hijau RGB, pendeteksian pada $[(\mathrm{S}>0.6)$ atau $(\mathrm{B}<0.25)$ atau ( $\mathrm{B}-\mathrm{S}>0.3)$ ] akan diabaikan. Untuk citra saturasi, pendeteksian pada $[(\mathrm{B}-\mathrm{S}>0.1)$ atau $(\mathrm{B}<0.25)$ atau $(\mathrm{S}>0.6$ dan $\mathrm{B}<0.85)$ atau $(\mathrm{B}=1)]$ akan diabaikan pula.

Pada permukaan air, pemantulan permukaan tanah (juga tumbuh-tumbuhan dan pepohonan) yang meluas dari tepi suatu permukaan air dapat mengitari sebagian atau semua badan air, tergantung pada lebar dan jaraknya dari air. Kisaran pemantulan ini secara kasar dapat dijadikan perkiraan objek yang dipantulkan. Harus diingat bahwa plot pemantulan akan selalu lebih rendah dari elevasi tanah yang sebenarnya.

Ciri air dapat kita dapatkan dengan menganalisis kisaran area pemantulan. Gambar 7A menunjukkan tingginya kesalahan cakupan warna dan tinggi citra yang dihasilkan dari Gambar 2. Pada kisaran area citra, piksel merah menunjukkan jarak semakin dekat dan piksel biru menunjukkan jarak semakin jauh. Piksel ungu menunjukkan di atas 100 meter. Piksel hitam menandai bahwa tidak ada data kisaran yang dihasilkan.

Ternyata, kisaran area pantulan yang dapat disegmentasikan cukup kompleks karena titik perhatiannya ke setiap objek yang dipantulkan. Pada saat objek semakin dekat dan tidak terkena langsung cahaya matahari, kegagalan deteksi semakin tinggi. Pengolahan lebih lanjut dari Gambar 7A. di atas dapat dilihat pada 2 gambar di sebelah kanan. Beberapa bagian yang penting dari tiap dari genangan yang besar berhasil dideteksi. Pada area tepi genangan yang tidak terlihat, pendeteksian diteruskan ke bagian bawah kolom itu sehingga piksel tanpa data kisaran juga diberi label piksel area pemantulan. Beberapa bagian pemantulan yang lemah dari tumbuh-tumbuhan yang berada jauh pun dapat dideteksi. Segmentasi dengan cara ini membuat jelasnya perbedaan antara pantulan objek di permukaan air dengan objeknya sendiri. Pada area pemantulan sudah pasti akan banyak ditemui campuran warna, yang dapat diidentifikasikan sebagai salah satu ciri air, sedangkan objeknya sendiri hanya terdiri dari satu warna saja. Namun, ada beberapa kasus di mana objek selain air itu sendiri bisa memantulkan objek lainnya. Gambar 8 menunjukkan kombinasi deteksi air dari penggabungan warna, tekstur, dan analisis kisaran area pantulan. Piksel yang terdiri atas satu, 2 atau 3 ciri air diberi warna biru, ungu, dan merah.

Seperti yang dijelaskan sebelumnya, pada saat pengambilan citra ditentukan pula suatu garis horison dari citra. Ciri air yang berada di bawah garis horizon yang memenuhi syarat, maka jika diketemukan segmentasi warna dugaan air di atas garis horison akan diabaikan (seperti pada Gambar 5 dan 6). Metode ini didasarkan pada prinsip fisika bahwa cahaya yang dipantulkan oleh permukaan air adalah terpolarisasi linier parsial dan fase polarisasinya menjadi serupa dengan keadaan cahaya di sekelilingnya. Air dapat dideteksi dengan melakukan perbandingan derajat polarisasi dan persamaan fase polarisasi tersebut.

Pada metode ini, ada 2 langkah analisis air yang digunakan, yaitu ekstrak informasi polarisasi dan pengolahan citra polarisasi. Berikut ini adalah citra sumber yang menjadi objek deteksi air yang digunakan dalam penelitian (Xie, 2007).
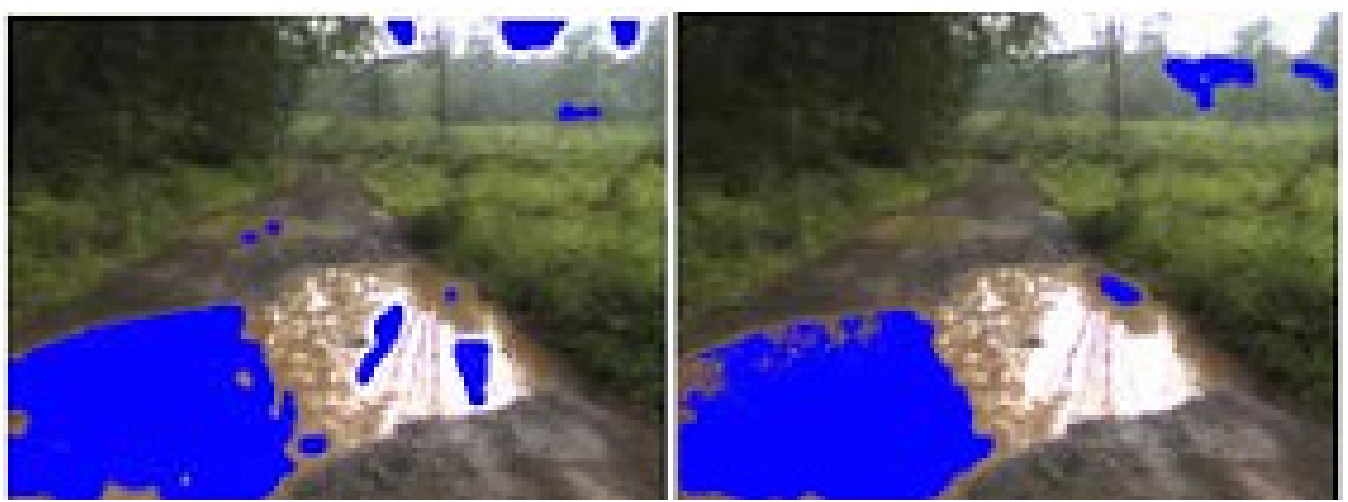

Gambar 6 Pengolahan Citra

(Sumber: Segmentasi Berdasarkan Tekstur dengan Menggunakan Variasi Threshold dari 13 Citra Kanal Hijau Rgb (Kiri) dan Citra Tersaturasi (Kanan) (Rankin, 2004))
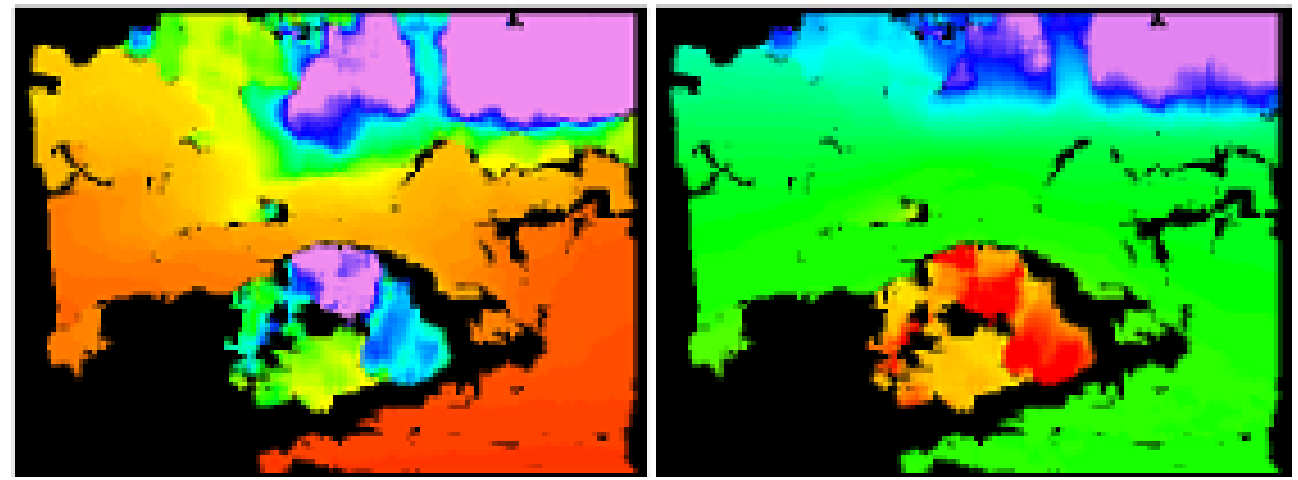

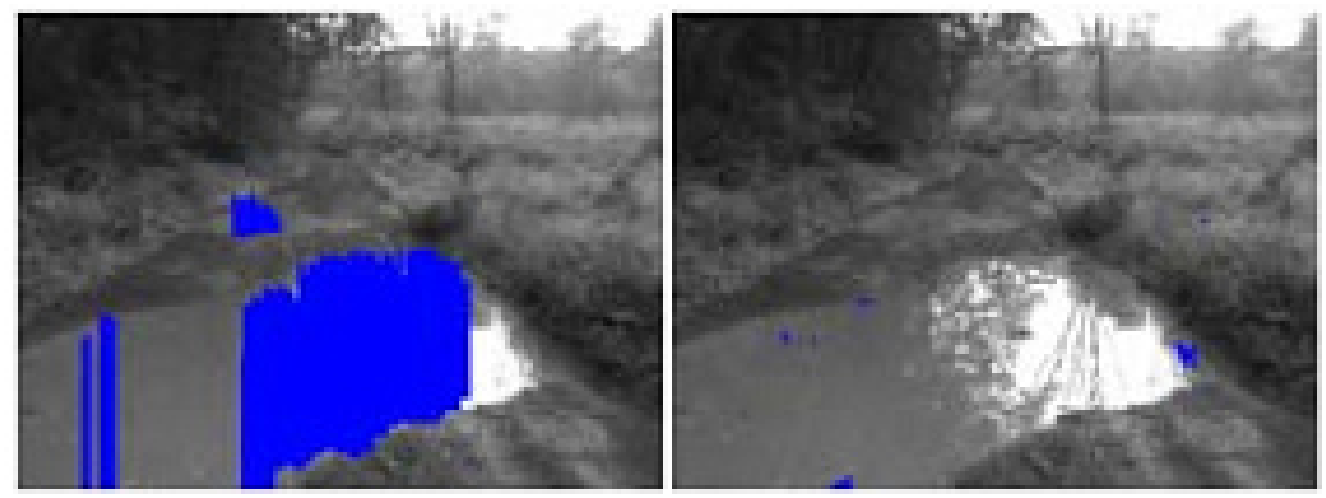

Gambar 7A Pengolahan Citra

Sumber: Segmentasi Awal dengan Analisis Kisaran Area Pantulan

Dan B. Segmentasi dengan Analisis Kisaran Area Pantulan (Rankin, 2004)

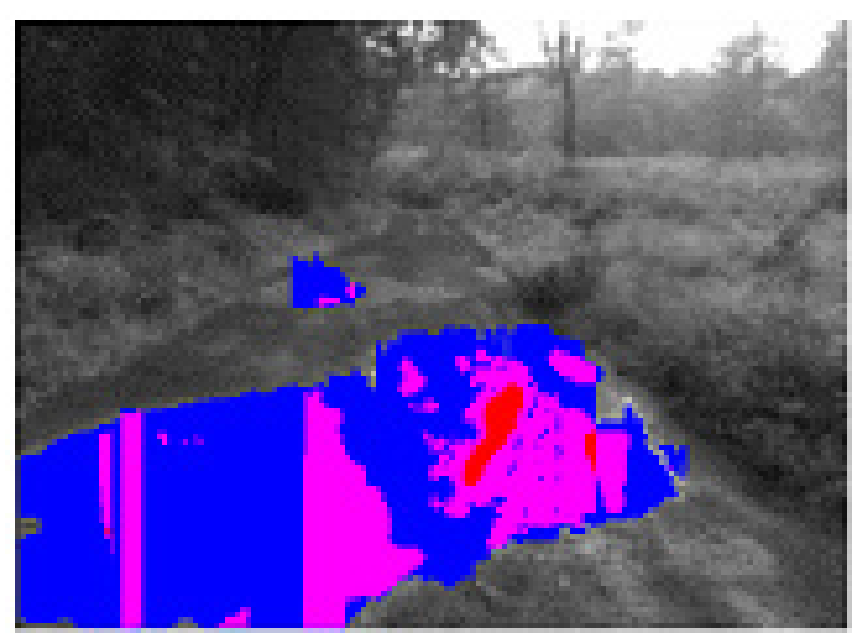

Gambar 8 Penggabungan Ciri Air 3 Sub Metode di Atas (Biru=Ciri Tunggal, Ungu=Dua Ciri, Merah=3 Ciri). Daerah Air yang Kecil dan Daerah di Atas Kaki Langit dan Roda Kendaraan UPV (dengan $>0.75 \mathrm{~m})$ Ditolak

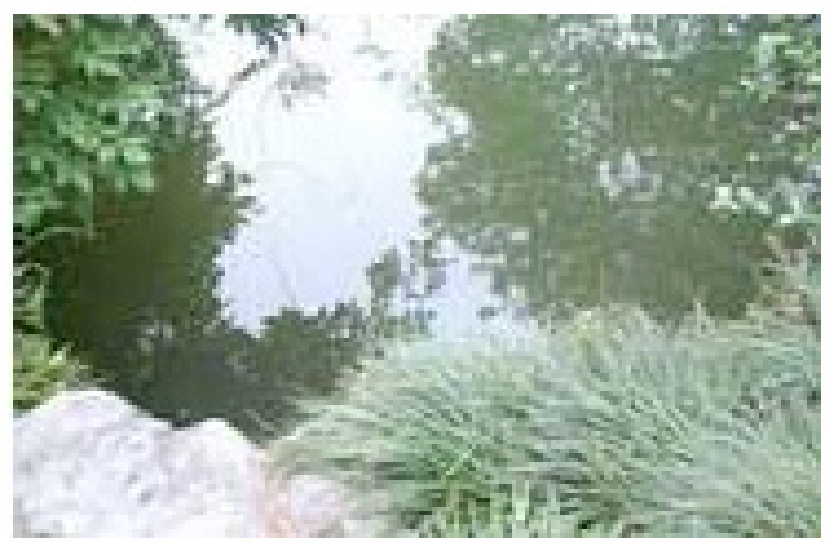

Gambar 9 Citra Sumber Permukaan Air yang Akan Dideteksi (Xie, 2007)

Polarisasi parsial linier dapat diukur pada level piksel radiasi cahaya yang melewati suatu filter polarisasi. Pancarannya akan bervariasi secara sinusoidal sesuai dengan orientasi filternya (Wolff, 1995). Persamaannya terdapat di bawah ini:
Fase polarisasi:

Fase $\theta=0.5 * \arctan ((\mathrm{I} 0+\mathrm{I} 90-2 \mathrm{I} 45) / \mathrm{I} 90-\mathrm{I} 0)$

Intensitas polarisasi:

Jika I90 < I0 [if $($ I45 $<$ I0) $\theta=\theta+90$ else $\theta=\theta+90$ ]

Intensitas I $=\mathrm{I} 0+\mathrm{I} 45$

Polarisasi parsial atau derajat polarisasi:

$\mathrm{P}=(\mathrm{I} 90-\mathrm{I} 0) /(\mathrm{I} 90-\mathrm{I} 0) \cos 2 \theta$

I0, I45 dan I90 adalah intensitas cahaya yang dipilih untuk memperoleh parameter derajat polarisasi dan fase polarisasi. Proses ekstraksi informasi polarisasi ini dilakukan dengan mengolah kombinasi citra yang ditangkap dengan memberikan kondisi seperti pada ketiga persamaan di atas dan ditampilkan dalam area warna HSV. Berikut ini adalah citra hasil ekstraksi parameter polarisasi menggunakan persamaan di atas.
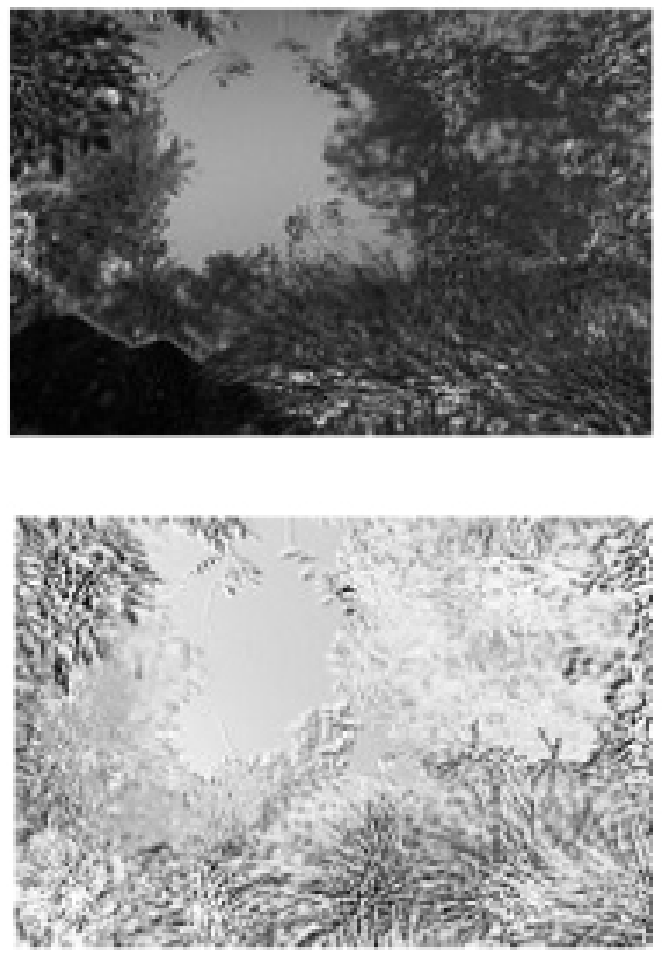

Gambar 10 Citra Permukaan Air Setelah Dihitung Berdasarkan Derajat Polarisasi (KIRI), dan Dihitung Berdasarkan Fase Polarisasi (KANAN) (Xie, 2007) 
Citra hasil perhitungan berdasarkan derajat polarisasi terlihat belum dapat membedakan secara detail antara pantulan tumbuh-tumbuhan pada permukaan air, sedangkan citra hasil perhitungan berdasarkan fase polarisasi ini dapat menunjukkan perbedaan intensitas antara objek pantulan dengan objek sesungguhnya. Inilah yang menjadi kunci identifikasi air memanfaatkan pantulan cahaya yang mengenainya.

Pada bagian ini dilakukan klasifikasi untuk segmentasi citra. Pada beberapa riset sebelumnya, metode segmentasi citra ini pada umumnya memusatkan pada parameter derajat polarisasi saja. Namun, pada beberapa keadaan di alam ditemui derajat polarisasi dari daerah air secara signifikan lebih besar dari scene cahaya sekitarnya ketika memantulkan langit, tetapi juga kadang hampir sama dengan scene sekitar ketika memantulkan tumbuh-tumbuhan di sekelilingnya. Jadi, mustahil jika hanya menggunakan derajat polarisasi untuk melakukan segmentasi semua badan (permukaan) air pada semua situasi di atas. Algoritma segmentasi yang digunakan adalah segmentasi threshold dan algoritma morfologi filter untuk menandai permukaan air. Persamaannya adalah sebagai berikut (Xie, 2007).

$$
S=\sum_{i, j} w(i, j)|\theta(i, j)-\bar{\theta}|
$$

Keterangan:

$\mathrm{S}=$ segmentasi similiar fase polarisasi

$\theta(i, j)$ mewakili fase tiap pixel pada citra dengan polarisasi fase

$\theta$ mewakili rata-rata nilai dari area tertentu pada citra dengan polarisasi fase

$w(i, j)$ mewakili lebar dari titik $(i, j)$, biasanya pilih $w(i, j)=1$

Algoritma segmentasi threshold ini digunakan untuk menandai wilayah pada citra yang diduga sebagai air dengan aturan semua area yang derajat polarisasinya lebih besar dari threshold akhir. Kemungkinannya adalah air, sedangkan algoritma morfologi filter adalah untuk menapis diskontinuitas yang terjadi pada algoritma segmentasi threshold.
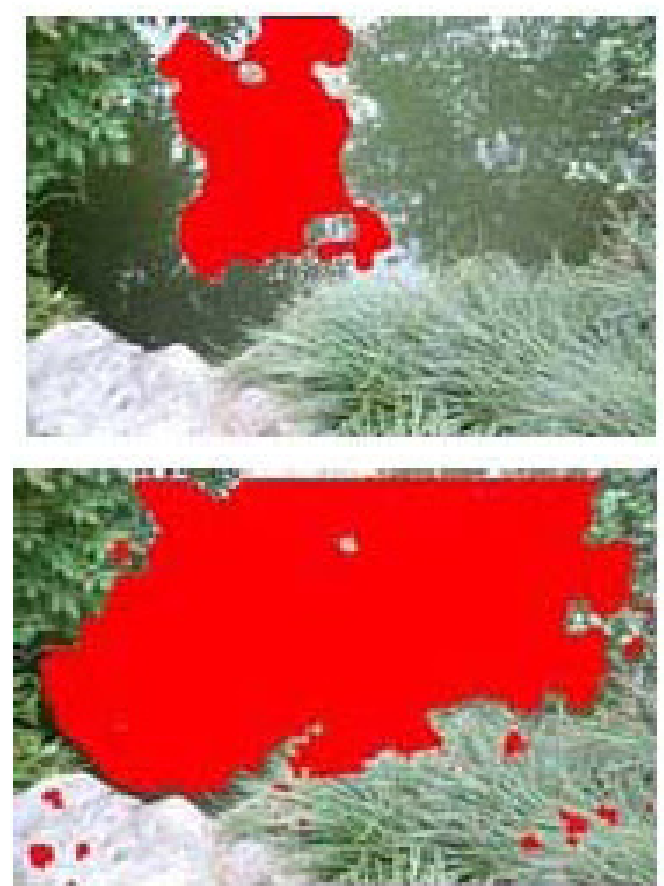

Gambar 11 Segmentasi Warna Citra Permukaan Air Berdasarkan Derajat Polarisasi (Kiri) dan Berdasarkan Fase Polarisasi (Kanan) (Xie, 2007)
Gambar 11 sebelah kiri adalah hasil segmentasi citra yang dihitung berdasarkan derajat polarisasi pada citra, namun hanya bidang yang langsung memantulkan langit yang dapat terdeteksi dengan baik, sedangkan untuk bidang yang memantulkan tumbuh-tumbuhan tidak terdeteksi. Sedangkan hasil dari penerapan algoritma segmentasi threshold pada citra yang dihitung berdasarkan fase polarisasi (Gambar 11 sebelah kanan) menunjukkan bahwa seluruh bidang air dapat dikenali. Beberapa titik segmentasi threshold akhir di luar genangan besar menandakan bahwa ada genangan kecil pada batu atau pada tanaman rumput. Perbandingan metode color imagery dan polarisasi cahaya, prinsip dasar perbandingan adalah bahwa 2 metode ini memiliki kesamaan dalam memanfaatkan pantulan cahaya pada permukaan air untuk dianalisis dan diidentifikasi. Lalu, kedua metode inipun menggunakan metode analisis memanfaatkan threshold (ambang) area warna HSV dalam segmentasi area yang diidentifikasi sebagai air.

Tabel 1 Perbandingan Metode Identifikasi Air

\begin{tabular}{|c|c|c|c|}
\hline No. & Keterangan & Metode Color imagery & Metode PolarisasiCahaya \\
\hline 1 & $\begin{array}{l}\text { Alat } \\
\text { penangkap } \\
\text { citra }\end{array}$ & $\begin{array}{l}\text { Camera CCD atau } \\
\text { sistem LADAR }\end{array}$ & $\begin{array}{l}\text { Camera CCD dengan filter } \\
\text { polarisasi }\end{array}$ \\
\hline 2 & $\begin{array}{l}\text { Skenario } \\
\text { penangkapan } \\
\text { citra }\end{array}$ & $\begin{array}{l}\text { Peralatan diatur dengan } \\
\text { sudut pantul yang } \\
\text { dapat diprediksikan. } \\
\text { Pengambilan cukup } \\
1 \text { kali. }\end{array}$ & $\begin{array}{l}\text { Peralatan diatur lebih } \\
\text { detail dengan } 2 \text { kombinasi, } \\
\text { yaitu } 3 \text { kamera dengan } 3 \\
\text { jenis filter berbeda atau } \\
\text { satu kamera dengan filter } \\
\text { yang diganti sebanyak } \\
3 \text { kali. }\end{array}$ \\
\hline 3 & $\begin{array}{l}\text { Metode } \\
\text { analisis ciri } \\
\text { air }\end{array}$ & $\begin{array}{l}4 \text { langkah, yaitu } \\
\text { identifikasi warna, } \\
\text { tekstur, analisis } \\
\text { kisaran pantulan dan } \\
\text { penggabungan } \\
\text { (8 algoritma) }\end{array}$ & $\begin{array}{l}2 \text { langkah, yaitu ekstrak } \\
\text { informasi polarisasi dan } \\
\text { segmentasi citra } \\
\text { ( } 3 \text { algoritma) }\end{array}$ \\
\hline 4 & Hasil & $\begin{array}{l}\text { Permukaan air } \\
\text { teridentifikasi dengan } \\
\text { baik }\end{array}$ & $\begin{array}{l}\text { Permukaan air } \\
\text { teridentifikasi dengan baik }\end{array}$ \\
\hline
\end{tabular}

Metode color imagery unggul dalam detail pengolahan dan kemudahan dalam mekanisme penangkapan citra. Kombinasi kamera CCD dengan sistem LADAR menawarkan efisiensi pengolahan citra sampai pada perkiraan jarak dari suatu permukaan air dan pengambilan citra cukup satu kali saja. Namun, pada metode analisis ciri air membutuhkan lebih banyak algoritma karena proses identifikasinya dalam area analisis intensitas warna, tekstur, dan kisaran pantulan cahaya. Masing-masing proses ini membutuhkan 2 alogritma, yaitu algoritma identifikasi dan segmentasi. Pengolahan bagian akhirnyapun membutuhkan 2 algoritma, yaitu algoritma penggabungan ciri air dan tapis untuk menghilangkan kesalahan deteksi pada metode yang digabungkan tersebut.

Metode polarisasi cahaya membutuhkan instalasi peralatan pengangkap citra yang lebih teliti, agar informasi polarisasi cahaya dari pantulan dapat ditangkap dengan baik. Pengambilan citra paling tidak dilakukan 3 kali dengan fase polarisasi yang berbeda-beda. Namun, metode ini lebih unggul pada saat analisis ciri air, yang hanya membutuhkan 3 algoritma saja, yaitu algoritma ektrak informasi polarisasi, segmentasi threshold, dan morfologi filter.

\section{SIMPULAN}

Pemilihan metode analisis ciri air pada alam terbuka tentunya tidak lepas dari aplikasi penggunaannya. Namun, efisiensi algoritma dengan tidak mengurangi kemampuan 
deteksinya adalah titik fokus yang penting pada penelitianpenelitian di bidang visi komputer ini. Metode analisis polarisasi cahaya yang dapat memberikan lebih banyak informasi dibandingkan dengan analisis intensitas cahaya secara konvensional, tentunya dapat dijadikan metode yang efisien dalam algoritma. Dengan demikian, penelitianpenelitian yang dilakukan untuk menemukan algoritma paling efektif dalam ekstraksi informasi polarisasi tersebut sangat dibutuhkan. Selain itu, penelitian perlu diarahkan untuk mengembangkan sistem penangkapan citra yang cukup praktis untuk metode polarisasi cahaya. Penelitian yang mencakup pembuatan jenis kamera khusus polarisasi cahaya, pembuatan jenis lensa polarisasi sampai kepada mekanisme instalasinya karena sampai saat ini skenario pengambilan citra dengan metode polarisasi citra ini masih cukup kompleks dan rentan terhadap kesalahan.

\section{DAFTAR PUSTAKA}

Cardani, D. (2001). Adventures in HSV space, Laboratorio de Robótica, Instituto Tecnológico Autónomo de México.

Goldstein, D. (2003). Polarized light, $2^{\text {nd }}$ ed., CRC Press, ISBN-13: 9780824740535 .

Matthies, L., Bellutta, P., and McHenry, M. (2003). Detecting water hazards for autonomous off-road navigation. Proceedings of SPIE Conference 5083: Unmanned Ground Vehicle Technology $V$, Orlando, FL, 2003: 231-242.

Rankin, A., Matthies, L., and Huertas, A. (2004). Daytime water detection by fusing multiple cues for autonomous off-road navigation. Proceedings of the 24th Army Science Conference, November 2004.
Xie, Bin., et al. (2007). Polarization-based water hazards detection for autonomous off-road navigation. Proceeding of 2007 IEEE/ RSJ International Confrence on Intelligent Robots and System, San diego, CA, USA.

Wolff, Lawrence B., dan A.G. Andreou: Polarization camera sensors. Image Vision Comput. 13(6): 497-510 (1995) 